\title{
The Effect of Maqashid Sharia on the Decision of Muzaki Paying Zakat in Organization of Zakat Management (OPZ) (Tawhidi Perspective Epistemology Approach)
}

\author{
Nurida Isnaeni, Yuswar Z. Basri, Tatik Mariyanti \\ willy.arafah@gmail.com
}

\begin{abstract}
Aim of this research is to know the influence of internalization of maqashidsharia towardmuzaki's decision of paying ZIS at Organization of Zakat Management (OPZ). This research is designed as a quantitative method, using Structural Equation Model-Partial Least Square (SEM-PLS) and using Tawhidi Epistemology approach. The result of research by using SEM method concluded that generally maqashid sharia as variable which influencedmuzaki's decision in paying ZIS. The implications results of this study are expected by the internalization of the maqashid sharia by incorporating Tawhidi Epistemology Approach could provide more understanding, attitude and action toward muzaki to be able to improve both quantity and quality of ZIS, thus becoming a Muslim and muslih, it is necessary to cooperate with various parties related to the Zakat, so as to maximize the potential that exist in answering social problems in Jambi Province.
\end{abstract}

Keywords: Maqashid sharia, social marketing, zakat infaksedekah (ZIS), zakat decisions, tawhidi epistemology

\section{INTRODUCTION}

Indonesia is the largest Muslim majority population country of 216.66 million people or with the percentage of Muslims as 85 percent of the total population (BPS, 2015). Based on Oxfam Indonesia's report and the International NGO Forum on Indonesia Development (INFID), Indonesia's economic inequality rankings are in the sixth worst position in the world. Indonesia's economic growth is considered stable enough and the proportion of people living in extreme poverty has been reduced about eight percent. However, Oxfam and INFID rate the achievements of economic growth has not been matched by a more equitable division of income. Over the past two decades, inequality between the richest groups and other groups in Indonesia has increased rapidly compared to countries in Southeast Asia. Besides that, the report also records the wealth of the four richest people in Indonesia equal to the combined wealth of the 100 million poorest people. (The Indonesian Institute, 2017).

The economic system adopted by the Prophet is rooted in principles derived from the Qur'an. The Qur'an which is the main source of Islamic teachings has established some rules as guidance for human activities in every aspect of their lives including in the economic field (Praja, 2012). So, Islam has arranged in such a way the distribution of wealth to overcome the problem of social inequality. Islam has already its own instrument to solve the problem, namely zakat. Zakat is an obligation for a Muslim who is deemed able based on Islamic criteria to spend between $2.5 \%-20 \%$ of the proportion of his wealth to be distributed to the whom financially disadvantaged. Umar bin Abdul Aziz and Harun Al Rashid are models of Islamic leaders who have succeeded in proving the effectiveness of this instrument in articulating and enhancing the welfare of their people, not only for the recipients of zakat (mustahiq) but for the provider zakat (muzaki).(Firmansyah,2013)

Zakat has power of income distribution primarily in the creation of justice and social welfare. In this effort, Islam provides a vast opportunity for the muzaki to distribute its income to the needy. Zakat is potential to increase the participation of Muslims in national development. The potential of zakat pull out in earnest and some Muslims can pay zakat, it will give very large amount of funds. This amount itself can give meaning to solve 
The Effect of Maqashid Sharia on the Decision of Muzaki Paying Zakat in Organization of Zakat Management (OPZ)(Tawhidi Perspective Epistemology Approach)

problems of poverty, education, religious development and social inequality, and can help accelerate success of national development. Through the right management, zakat is possible to build economic growth as well as equal distribution of income, economic growth with equity (A.M. Saefuddin, 1996).

The management of zakat in Southeast Asia is divided into three, namely the management of zakat by government, nongovernment and organization (NGO). While in Indonesia, zakat funding is not separated from the role of zakat management organization (OPZ). In which dividedinto two types of OPZ, where they have the same position, namely BadanAmil Zakat (BAZNAS) and LembagaAmil Zakat (LAZ). BAZNAS is an OPZ formed by the government, while LAZ is the OPZ which is fully formed by the community and confirmed by the government.

The development and performance of zakat institutions is relatively slow. Some studies report that zakat collection in Muslim countries is on average very low, less than 1\% of GDP (Kahf, 1999) although at the country level it may range from 0-8\% of GDP (Ahmed, 2004) (in Kasri , 2016).

A number of studies have discussed the potential of zakat in Indonesia. The survey of the Public Interest Research and Advocacy Center (PIRAC) shows that the potential of zakat in Indonesia has an annual increasing trend. Based on a survey of 10 major cities in Indonesia, PIRAC shows that the average potential of zakat for everymuzaki reached Rp 684,550.00 in 2007, increase by previous Rp 416,000.00 in 2004. PEBS FEUI used the number of muzaki approach from the Indonesian Muslim population within assumption that 95 percent of muzaki paying zakat, it can be projected the potential of zakat fund accumulation in 2009 reached Rp 12.7 trillion (Indonesia Economic Outlook, 2010).

Growth of ZIS revenue has also increased. This is a good indication, but if seen and compared between the expected potential and the majority of the population of Islam is still far awayof expectation. Recent studies conducted by BAZNAS, said that the potential of national zakat in 2015 has reached Rp 286 trillion. Regardless of the potential that can be estimated and predicted, the reality of zakat receipts up to now is still very far from expectations, the data table above shows the amount of zakat receipts reached 3.7 trillion in 2015. This figure is clearly far from number of potential that exists.

The problem of zakat inequality that occurred at the national level also occurred in Jambi province. Based on research that conducted by (LIPI, 2010) using zakat level of at least $2.5 \%$ of each sector of GRDP. It is estimated that the potential of zakat in Jambi province in 2016 reached Rp 3.2 trillion and increased to Rp 3.4 trillion in 2017. This is in line with the growth of GRDP. However the zakat potential of these two sectors is still untouched by the zakat management agency, especially by the Regional Amil Zakat Agency (BAZNAS) of Jambi province.

Based on the results of a simple calculation of the estimated potential of zakat above, it turns out the potential of zakat in Jambi province is quite large. Based on the report of the Budget Agency (Banggar) of Jambi Provincial DPRD, Jambi provincial revenue in 2017 is targeted at $\mathrm{Rp} 4.127$ trillion or an increase of 15.75 percent from the 2016 Budget (APBD) of Rp3.442 trillion. The targeted revenues consisted of Local Own Revenue (PAD) equal to Rp1,393 trillion more and a balance fund of Rp2,730 trillion more. When compared with the original income of the region equal to $\mathrm{Rp} 1,393$ trillion then the amount of zakat potential is almost 3 times the PAD obtained by local government. This can be interpreted, if the potential of zakat can be extracted optimally, then a new source of development funds that can be used to eradicate Muslims from poverty is quite large, when viewed from the realization of Zakat, Infaq and Sedekah (ZIS) and other receipts that can be collected by Baznas Jambi province only reached $\mathrm{Rp} 10$ billion in 2016. Compared with the estimated potential of zakat Jambi province in 2017 equal to Rp 3.4 trillion, then therealization to potential ratio is still very small at $0.03 \%$.

The purpose of this study describes how the internalization of the role of the maqashid sharia toward muzaki's decision of paying zakat to the Organization of Zakat (OPZ) through different approaches. The difference is 
The Effect of Maqashid Sharia on the Decision of Muzaki Paying Zakat in Organization of Zakat Management (OPZ)(Tawhidi Perspective Epistemology Approach)

derived from a belief or ketauhidan to Allah SWT (everything comes from God and will return to Allah), derived from the teachings of the Qur'an and As-Sunnah as a source of knowledge, a model built that reflected to the shuratic process and model relations built multidimensional attention to the interests of life in the world and the hereafter. That approach is called the tawhidi epistemology approach.

The formulation of the proposed problem is whether the internalization of maqashid sharia has a significant influence on the muzaki's decision paying zakat through Organization of Zakat Management.

\section{LITERATURE REVIEW}

\section{Maqashid Sharia}

Al-Qur'an as a source of law and religious teachings, in order to realize the teachings of religion for the benefit of human beings in the world and in the hereafter based on the analysis of Islamic law theorists (ushuliyyin), there are at least five basic elements that must be maintained and realized, namely preserved generation (hifzh al-nafs), preserved heritage (hifzh al-nasl), preserved property (hifzh al-mal), and preserved the intellect (hifzh al-aql).

ImāmAbūHāmid al-Ghazālī (in Chapra, 2013) classifies maqasid into five main categories by stating that:

"The very objective of the Shari ah is to promote the well-Being of the people, which lies in safeguarding their faith (din), their self (nafs), their intellect (aql), their posterity (nasl), and their wealth (mal). Whatever ensures the safeguard of these five serves public interest and is desirable, and whatever hurts them is against public interest and its removal is desirable"(Chapra, Bank, Clark-Murphy, Gerrans, \& Speelman, 2009)

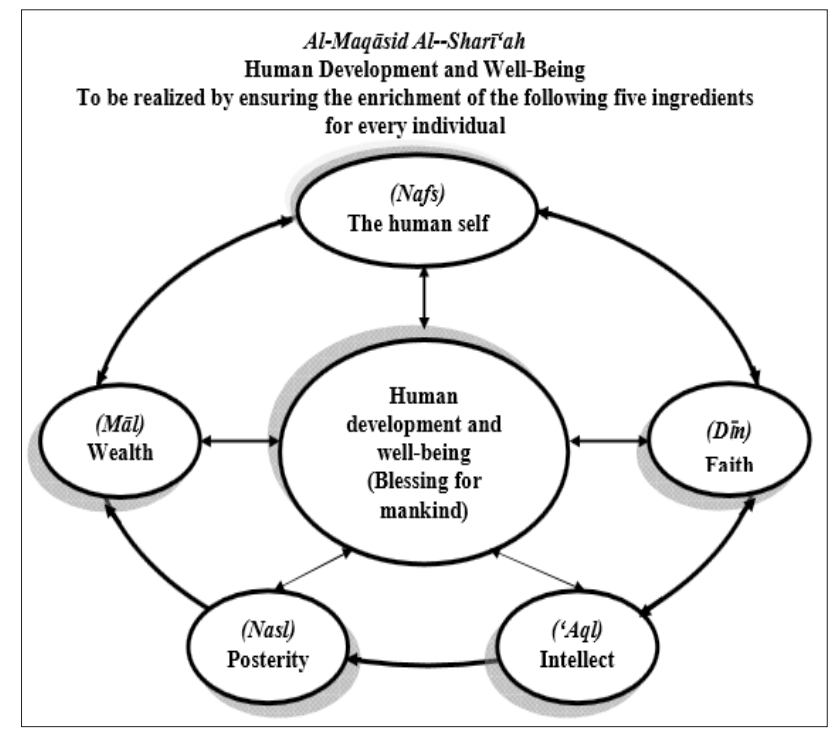

Figure1. Al-Maqasid Al-Shari'ah Human Development and Well-Being to be Realized by Ensuring The Enrichment of Following Five Ingredients for Every Individual

Source :Chapra, 2013

Islamic Sharia is a living rule that comes from Allah ta'ala, it is the guide of life for all mankind. As a life guide it has a primary goal that is acceptable to all mankind. The purpose of the Islamic Sharia is for the good of all mankind. In the scope of ushulfiqh this goal is called maqashid as-syari'ah namely the purpose and goal of Islamic Sharia. Maqashid sharia in term is the objectives of Islamic law contained in every rule. Imam AsySyathibi reveals the sharia and its function for man as his words in the book of al-Muwwafaqat: 
The Effect of Maqashid Sharia on the Decision of Muzaki Paying Zakat in Organization of Zakat Management (OPZ)(Tawhidi Perspective Epistemology Approach)

"Truly the Sharia is set in aimed for the establishment of humanity in the world and the Hereafter." The laws are enacted for the benefit of the slaves.

The values contained in the maqashid sharia have already existed since era of the Prophet. Then, nowaday many figures who helped participated on it, some of them are Al-Juwaini, AL-Ghazali, IbunuTaimiyyah, AsySyatibi, UmerChapra, JaserAuda, the measurement ofmaqashid sharia is used also various. Start from classic to contemporary perspectives.

\section{Zakat}

Zakat is one of the important pillars of Islamicteachings, the third pillar in the pillars of Islam. Etymologically, zakat means developing (an-namaa), sanctifying (at-thaharatu) and blessing (al-barakatu). While terminologically, zakat means the removal of some property with certain conditions to be given to a certain group (mustahik) and also certain requirements.

"Zakat is worship maaliyahijtima'iyyah which has a very important position, strategic, and decisive, both seen from the side of Islamic teachings as well as from the side of welfare development of the people. As a principal worship, zakat is one of the pillars of the five pillars of Islam, as revealed in the various hadiths of the Prophet, so that their existence is regarded as ma'luumminad-diinbidhdharuurah or known automatically and is an absolute part of someone Islamiclevel"(Hafiduddin, 2004).

One of the verses in the Qur'an which is the legal basis for Zakat sanctuary is found in Q.S A-Baqarah [2]: 43 and verse 267

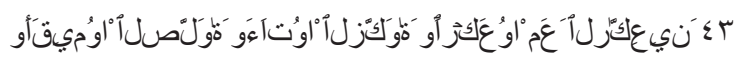

"And establish prayer, make zakat and bow with the people who bow (congregational prayer)". (Q.s al-Baqarah [2]: 43).

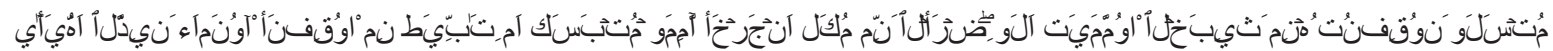

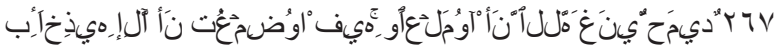

"O ye who believe! Spend (in the way of Allah) part of your good works, and some of what We send out from the earth to you. And do not choose bad or bad then you spend from it. Though you do not want to take it except by squinting at it. And know that Allah is most wealthy again Praiseworthy. "(Q.s al-Baqarah [2]: 267).

\section{The Decision of Paying Zakat}

(Schiffman-Kanuk, 2007) says that the decision as a selection of two or more alternative options, in other words the availability of more than one choice is a must in making decision. Based on the description above, the process of purchasing decision used in this research refers to the theory proposed by Engel (1995), namely the decision-making process of purchasing refers to consistent and prudent actions taken to meet the needs. Moreover, it will be discussed about the stages in buying.

According to Kotler and Armstrong (2012), consumers will pass the 5 (five) stage of the purchase decision process. The steps are illustrated in Figure 2.7 below:

Need
recognition $\rightarrow \begin{gathered}\text { Information } \\ \text { search }\end{gathered} \rightarrow \begin{gathered}\text { Evaluation of } \\ \text { alternatives }\end{gathered} \rightarrow \begin{gathered}\text { Purchase } \\ \text { decision }\end{gathered} \rightarrow \begin{gathered}\text { Postpurchase } \\ \text { behavior }\end{gathered}$

Figure2. Purchase Decision Process

Source: Kotler and Armstrong (2012: 176) 
The Effect of Maqashid Sharia on the Decision of Muzaki Paying Zakat in Organization of Zakat Management (OPZ)(Tawhidi Perspective Epistemology Approach)

The series of consumer purchasing decision processes (Kotler and Armstrong, (2012), Engel et al. (1994) and Lamb et al. (2001), there are five stages:

1. Need recognition

2. Information search

3. Evaluation of alternatives

\section{Purchase decision}

\section{Post-purchase behavior}

Man will always be faced with various choices related to his life. Decision-making will always be needed in every choice. Choice made by a Muslim is one of the test, with a firm Allah Almighty declaring that every believing Muslim will always be given the exam. Allah SWT wants different human circumstances as a test. The difficulty exam, the poverty test, and the possessing of wealthare also a test. The benchmark of glory and humiliation of someone is his obedience to Allah SubhanahuwaTa'ala. As described in the following verse:

"Does the man think that they are left (alone) saying: 'We have believed', while they are not tested again? And verily we have tested those before them, verily Allah knows those who are truthful, and verily He knows those who lie. "[QS. Al-Ankabut: 2-3]

"We will indeed tempt you with little fear, famine, lack of wealth, soul and fruits. And give good news to those who are patient".

"And spend (your treasures) in the way of Allah, and do not throw yourself into destruction, and do good thing, truly Allah loves those who do good." (Q.S. Al-Baqarah: 195)

"Or do you (do so): how do you decide?" (Q.S. Al-Qalam: 36)

Through the verse above, Allah SWT explains that every believer will be given a test or a problem, and when faced a problem, humans will be faced the decision-making process related to solve the problem. The attitude of a person in dealing with a problem totally different, and also vary.Decision-making can be interpreted as a process of selecting the best alternative by many alternatives which considered as the most efficient in accordance with the situation.

\section{Tawhidi String Relation (TSR)}

In Islam the meaning of wealth both individually and socially are interrelated in circular causality. Islamic law affirms that personal wealth and social wealth in the same way affectthe individual and society (Choudhury, 2003).

According to Choudury (1999), in Tawhiidi String Relation (TSR) which is the main source of all science (primordial stock of knowledge) is the Qur'an, for it is the Word of Allah SWT. The knowledge that exists in the Qur'an has absolutely truth, covered all life comprehensively (complete) and therefore cannot be reduced or added (irreducible). So that the science built must be refer to the knowledge of the oneness of Allah (tauhid) as the source of all knowledge. But the Qur'an essentially contains no practical knowledge, but rather a general principle. The verses of the Qur'an are implemented in real manners by the Messenger of Allah, therefore AsSunah is also the source of the next science. The Qur'an and As-Sunnah can be elaborated in laws using the epistemological deduction method, which draws the general principles contained in both sources to be applied in individual reality.

According to (Maryanti, 2011), the Qur'an is given to humans in order that humans make this epistemological order symbolized by $(\Omega, S)$, according to the Qur'an, the science is a revelation revealed to man through the 
The Effect of Maqashid Sharia on the Decision of Muzaki Paying Zakat in Organization of Zakat Management (OPZ)(Tawhidi Perspective Epistemology Approach)

"suratic process". Suratic process is a process that deals with humans and nature. In this system will appear strong interaction. Through interaction emerges integration as a sign of a unified consensus. This integration, in turn, is followed by a process of epistemological evolution in the Q.SAS-Syuroverse 49.

With this understanding of the relationship humans and society create a world order based on the Qur'an and Sunnah and the knowledge they possess in the subsequent process of knowledge and humankind met through the process of deliberation (Suraticproces). Therefore, through the interaction and integration between them, and through the gradual development process the Social Wellbeing Function arises, this is denoted by $W(\theta, X(\theta))$.

\section{Types and Data Sources}

In this study the type of data used is the primary data, that data sourced from respondents directly, in this case is the donor (muzaki) who pays ZIS through OPZ. In determining the sample of respondents, researchers made a choice on the National Amil Zakat Agency (BAZNAS) contained in the city of Jambi. By the number of respondents is as many as 100 people.

\section{RESULT AND DISCUSSION}

\section{Analysis of Research Result with Method of Structural Equation Model-Partial Least Square (SEM-PLS)}

This research used Structural Equation Modeling (SEM) method of Partial Least Square (PLS) with three main reasons, because it has not assumed normal distribution (free distribution), has not assumed data in certain measurement scale and theory used still in development process for prediction purpose (Ghazali, 2014: 29-31). Basically the SEM-PLS method consists of two measurement models, namely the reflexive measurement model (Outer model) and the structural measurement model (Inner model).

\section{Evaluation of Reflexive Measurement / Evaluation Measurement (Outer) Model}

\section{Test Validity}

Test Validity is done as a condition before this data is processed by the next process. The value of this validity test can be seen from the value of loading factor which can be seen directly from the output of the resulting image. The measurement standard used is at least 0.50 . Based on the results of the model processing can be seen in Figure 1.

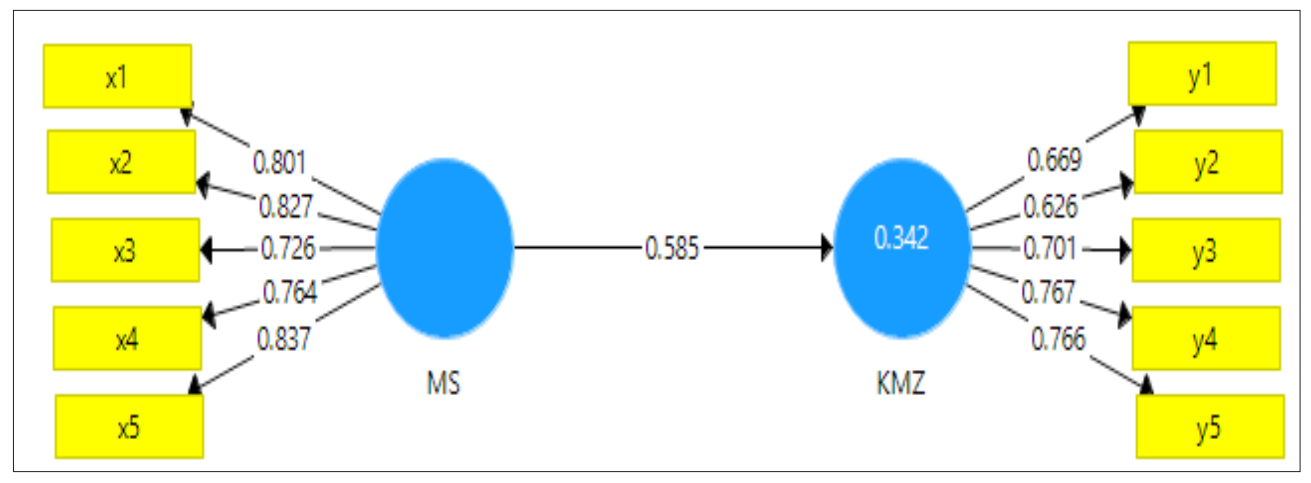

Figure1. Display Results PLS Algorithm

Source: PLS Processing Results, 2018

From the results of the model processing seen all reflective indicators are more than 0.50. It means that all indicators are valid and can be used to perform further data processing. The result of validity test from the reflective indicators of collision variable of this research model can be seen in Table 1.2. The number of valid 
The Effect of Maqashid Sharia on the Decision of Muzaki Paying Zakat in Organization of Zakat Management (OPZ)(Tawhidi Perspective Epistemology Approach)

indicators in this model equaled to 10, which are five indicators for maqashidsharia constructs $(\mathrm{X} 1, \mathrm{X} 2, \mathrm{X} 3, \mathrm{X} 4$ and X5); Five indicators for constructing Paying-decisions ZIS (Y1, Y2, Y3, Y4, and Y5).

Table1. Test Validity Indicator Reflective Constructs Research Variables

\begin{tabular}{|c|c|c|c|c|}
\hline No & $\begin{array}{c}\text { Name } \\
\text { Construct/Variabel }\end{array}$ & Indicator & $\begin{array}{c}\text { Value Loading } \\
\text { Factor }>0,50\end{array}$ & Description \\
\hline \multirow[t]{5}{*}{1.} & \multirow[t]{5}{*}{ Maqashid sharia / MS (X) } & Hifdz Ad-Dien (X1) & 0,801 & Valid \\
\hline & & Hifdz An-Nafs (X2) & 0,827 & Valid \\
\hline & & Hifdz Al-Aql (X3) & 0,726 & Valid \\
\hline & & Hifdz An-Nasb (X4) & 0,764 & Valid \\
\hline & & Hifdz Al-Maal (X5) & 0,837 & Valid \\
\hline \multirow[t]{5}{*}{2.} & \multirow[t]{5}{*}{ Decision of paying ZIS / (Y) } & Introduction of Requirement (Y1) & 0,669 & Valid \\
\hline & & Searching of Information (Y2) & 0,626 & Valid \\
\hline & & Alternative Evaluation (Y3) & 0,701 & Valid \\
\hline & & \begin{tabular}{|l} 
Decision of Paying ZIS (Y5) \\
\end{tabular} & 0,767 & Valid \\
\hline & & Postpaid Behavior ZIS (Y6) & 0,766 & Valid \\
\hline
\end{tabular}

Source: Smart PLS 3.0 (Data Processing Results)

\section{Convergent Validity}

Convergent Validity is a measure of the validity of the reflexive indicator as a variable gauge that can be seen from the outer loading of each variable indicator. An indicator is said to have good reliability, if the outer loading value is above 0.70 (Jonathan Sarwono, 2014). While the value of outer loading 0.50 can still be tolerated to be included in the model that is still under development (Ghozali, 2015).

Convergent Validity can be tested through two stages by looking at outer loading, Average Variance Extracted $(A V E)$. In this study there are 3 constructs with the number of indicators between 5 to 6 indicators with a scale of 1 to 5.

The following Average Variance Extracted (AVE) obtained from the test results of the measurement model in this study:

Table2. Average Variance Extracted (AVE) and Communality

\begin{tabular}{|l|c|}
\hline Constructs/Latent Variables & AVE \\
\hline $\mathrm{X}$ (Maqashidsyariah) & 0,501 \\
\hline Y (Zakat Payment Decision) & 0,627 \\
\hline
\end{tabular}

Source: PLS Processing Results, 2018

Based on the results of the measurement model test shown in Figure 4.1 and table 4.1 can be explained as follows:

a. The Maqashid sharia (X) construct is measured using X1-X5. Four indicators have a loading factor above 0.70 , AVE and communality value $>0.5$.

b. The Zakat Payment Decision (Y) construct is measured using Y1-Y5. Three indicators have loading factor above 0.7 while two indicators have factor loading value of 0.669 and 0.629 , but in accordance with the opinion of Ghozali (2015), that for the model still under development, then the loading factor below 0.70 is still tolerated and put in model. AVE value 0.5. 
The Effect of Maqashid Sharia on the Decision of Muzaki Paying Zakat in Organization of Zakat Management (OPZ)(Tawhidi Perspective Epistemology Approach)

Based on the loading factor results above it can be concluded that the construct has a good convergent validity.

\section{Discriminant Validity}

Discriminant validity testing is performed to prove whether the indicator on a construct will have the greatest loading factor in the construct formed rather than loading factor with the other constructs. It can be seen cross loading in table 4.2 below:

Table3. Cross Loading Value

\begin{tabular}{|c|c|c|}
\hline & X (Maqashid Sharia) & Y (Decision of Payment Zakat) \\
\hline $\mathbf{x 1}$ & 0,801 & 0,548 \\
\hline $\mathbf{x 2}$ & 0,827 & 0,389 \\
\hline $\mathbf{x 3}$ & 0,726 & 0,342 \\
\hline $\mathbf{x 4}$ & 0,764 & 0,435 \\
\hline $\mathbf{x} 5$ & 0,837 & 0,538 \\
\hline $\mathbf{y 1}$ & 0,600 & 0,669 \\
\hline $\mathbf{y 2}$ & 0,251 & 0,626 \\
\hline $\mathbf{y 3}$ & 0,308 & 0,701 \\
\hline $\mathbf{y 4}$ & 0,348 & 0,767 \\
\hline $\mathbf{y 5}$ & 0,367 & 0,766 \\
\hline
\end{tabular}

Source: PLS Processing Results, 2018

Based on table 3 above, the discriminant validity value shows good crossloading value because the correlation value of the indicator to the construct is higher than the correlation value of the indicator with other constructs. As illustration of loading factor X1 (indicator question for maqashid sharia) is equal to 0,801 higher than loading factor with other construct, that is $\mathrm{Y}(0,548)$. Thus, latent constructs predict indicators on their blocks better than indicators in other blocks.

\section{Composite Reliability and Cronbach's alpha}

Besides construct validity test, construct reliability test is also measured by composite reliability and cronbach's alpha from indicators that measure construct. The following is the result of composite reliability testing and cronbach's alpha from Smart PLS:

Table4. Composite reliability and cronbach's alpha Value

\begin{tabular}{|l|c|c|}
\hline \multicolumn{1}{|c|}{ Konstruk/Variabel laten } & Cronbach`s Alpha & Composite Reliability \\
\hline X Maqashid Sharia & 0,766 & 0,833 \\
\hline Y Decision of Payment Zakat & 0,853 & 0,894 \\
\hline
\end{tabular}

Source : PLS Processing Results,2018

The construct is considered to be reliable if it has a composite reliability value above 0.70 and cronbach's alpha above 0.60. From the output of Smart PLS above all constructs have composite reliability values above 0.70 and cronbach's alpha above 0.60 . So it can be concluded that the construct has good reliability. 
The Effect of Maqashid Sharia on the Decision of Muzaki Paying Zakat in Organization of Zakat Management (OPZ)(Tawhidi Perspective Epistemology Approach)

\section{Structural Model Testing (Inner Model)}

The structural model in the PLS is evaluated by using R2 for the dependent variable and the path coefficient value for the independent variable which assessed its significance based on the t-statistic value of each path. The structural model of this research can be seen in the following figure:

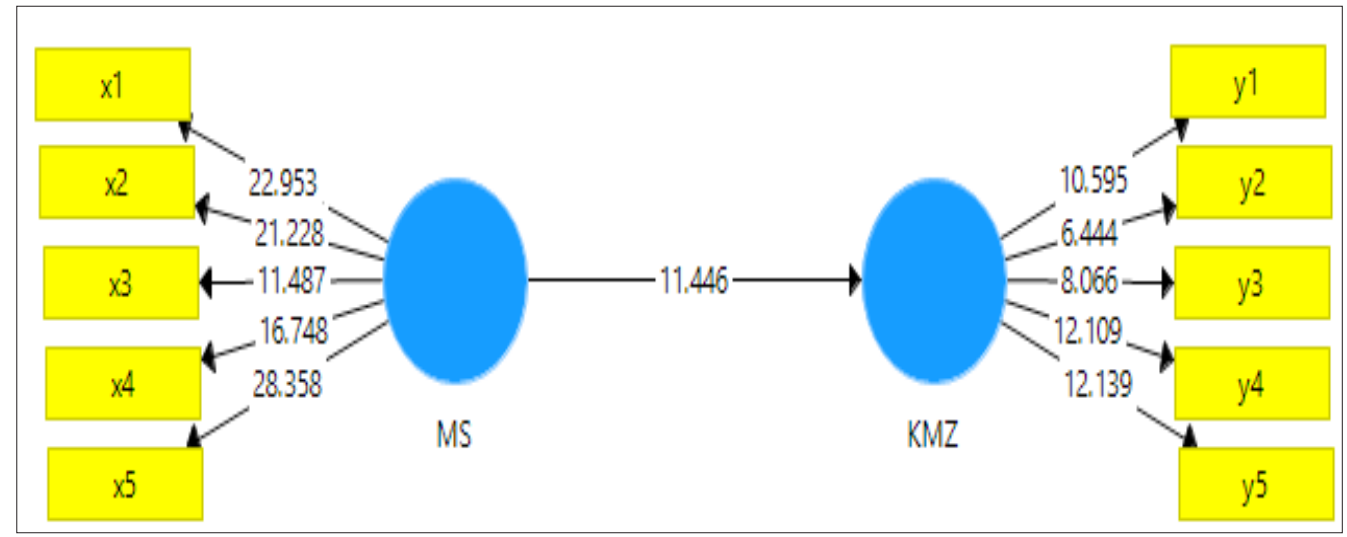

Figure2. Display Results Bootstrapping PLS

Source: PLS Processing Results, 2018

Assessing the model with PLS starts by looking at R2 for each dependent latent variable. The interpretation is similar to the interpretation of the regression that the variation of the dependent variable is explained by the independent variable of R2x 100\%, while the remaining 100\% - (R2x 100\%) is influenced by other factors outside the model. Changes in R2 values can be used to assess the effect of certain latent independent variables on latent dependent variables whether they have substantive influences (Ghozali, 2014: 42). The R2 yield of 0.33 indicates that the "moderate" model (Chin, 1998 in Ghozali, 2012: 42).

Table5. Coefficient of Determination (R2)

\begin{tabular}{|c|c|}
\hline \multicolumn{1}{|c|}{ Variabel } & R Square \\
\hline Y (decision of Payment Zakat) & 0,342 \\
\hline
\end{tabular}

Source: PLS Processing Results, 2018

Based on the analysis results in table 1.5, or the results of Coefficient Determination test (R2) note that:

Variables of maqashid sharia $(\mathrm{X})$ affect the variable decision of paying zakat $(\mathrm{Y})$ equal of 0.342 or $34.2 \%$. While the rest equal to $68,71 \%$ other influenced by variable other than variable.

Assessing the significance of the prediction model in testing the structural model, it can be seen from the t-statistic value between the independent variables to the dependent variable in the Path Coefficient table in the Smart PLS output below:

Table6. Path Coefficient

\begin{tabular}{|l|c|c|c|c|c|}
\hline & Original Sample & Sample Mean & Standard Deviation & T Statistics & P Values \\
\hline $\begin{array}{l}\text { X (Maqashid sharia) } \\
\text {-> Y Decision of } \\
\text { payment zakat) }\end{array}$ & 0,585 & 0,603 & 0,051 & 11,446 & 0,000 \\
\hline
\end{tabular}

Source: PLS Processing Results, 2018 
The Effect of Maqashid Sharia on the Decision of Muzaki Paying Zakat in Organization of Zakat Management (OPZ)(Tawhidi Perspective Epistemology Approach)

\section{Discussion of research results Structural Equation Modeling-Partial Least Square (SEM-PLS)}

Hypothesis testing had been done to see whether maqashid sharia (X) has a positive effect toward decision of paying zakat (Y). Based onthe table 4.5 above can be seen the original value of sample $\mathrm{X}$ is equal to 0,585 with significance below $5 \%$ indicated by t-statistic value 11,446 bigger than t-table value equal to 1,96. The positive original sample values indicate that maqashid sharia $(\mathrm{X})$ has a positive effect on the decision to pay Zakat (Y). Based on the test results can be concluded that the research hypothesis accepted.

\section{Discussion of TawhidyEpisthemology Approach, Maqashidsyariah and ZIS Paying Decision}

Generally it can be explained that the higher level of Muzaki'sunderstandingtoward values which contained in the Maqashid sharia both can be perceived by personal, family and community had been shown by more confident and motivated to pay ZIS in the BAZ / LAZ. The indicators which contained in the variables of the Maqashid sharia are five namely maintaining the religion (Hifdz Ad-Din), maintaining the soul (Hifdz An-Nafs), maintaining the mind (HifdzAl'Aql), maintaining offspring (Hifdz An-Nasb) and maintaining the property (Hifdz Al-Maal).

The results of this study have similarities with some previous research, such as: Farida (2008) using regression analysis method to examine the influence of Religiosity Index on the decision of muzaki paying zakat, whose results each have significant effect on individual decision whether to pay zakat or not. Musab (2011) also conducted a similar study but with a sample of muzaki for zakat in LAZIS NU Yogyakarta, by examining the variables of religiosity, income and service factors as independent variables. The result is these three variables also positively affect the tendency of Yogyakarta people to pay zakat in LAZIS NU Yogyakarta.

Research that has been done by (abuzar, 2006)states that There is a significant relationship between the level of understanding and attitudes toward obligation of zakat with a person's awareness to pay zakat. Obviously, the effect given is only 27.7 percent. That is, 72.3 percent of a person's awareness to distribute zakat is influenced by other factors, such as high levels of net income, the regulatory firmness of the local government related to zakat, a person's concern for poverty in the neighborhood, as well as public awareness and trust in zakat management institutions. The high level of understanding toward zakat and community attitudes towards zakat obligations that are positively need to be maintained. However, the low contribution of understanding and attitudes toward zakat obligation in encouraging the awareness of someone to zakat, it is necessary to have special efforts to be done by the parties concerned to give or grow awareness for zakat.

In the term of Tawhidy Epistemology Approach, Islamic Sharia is the rule of life that comes from Allah ta'ala, it is the guide of life for all mankind. As the guidance it has a primary goal that is acceptable to all mankind. The purpose of the Islamic Sharia is for the good of all mankind. In the scope of ushulfiqh this goal is called maqashid as-syari'ah namely the purpose and goal of Islamic Sharia. As a Muslim the obligation to study the science of religion is a must for every Muslim, so it should be as a Muslim understand the essence of which is contained in the value of Maqashid sharia in order to provide guidance in life, so as to reveal the wisdom of every Sharia which is given and believe that everything comes from God is good and gives kindliness for life. The duty of studying the science of religion is contained in the following Qur'an verse:

The word of Allah Ta'ala,

"And say, 'O my Rabb, add me knowledge'”. (SuraThaaha [20]: 114) then IbnHajar Al-Asqalanirahimahullah said,

"The Word of Allah Ta'ala (which means), 'O my Rabb, add me the science' contains a firm proposition of virtue. For Allah Almighty does not command His Prophet sallallaahu 'alaihiwasallam to request additional things except 
The Effect of Maqashid Sharia on the Decision of Muzaki Paying Zakat in Organization of Zakat Management (OPZ)(Tawhidi Perspective Epistemology Approach)

(additional) knowledge. As for what is meant by (word) science here is science syar'i. That is the science that will make a mukallaf know his duty in the form of worship and muamalah, also the knowledge of God and His attributes, what rights should be do in worshiping Him, and sanctify Him from various deficiencies. (FathulBaari, 1/92)

In the Islamic perspective, seeking a compulsory science is a science related to religious obligations and the prohibition of sharia. Every Muslim must have knowledge about prayer, fasting, zakat and hajj and all aspect related to him because all of this is obligatory in Islam to be done by every individual who is baligh and sensibly healthy therefore he must have knowledge. Associated with the obligation of prayer, then in addition to knowing the rules of prayer we must also understand ablution, unclean and way of sanctify, the case that abrogates ablution, and so on. Italso related to fasting, zakat and hajj. In the rule of fiqh it is said: (بجاووفنبال إبجاولاحتيالم) "A compulsory thing that cannot be perfect except in the presence of something, then something also becomes obligatory."

In line of Tawhidy Epistemology Approach, it can be explained that maqashid sharia conducted through the process of knowledge based on Islamic values will be continuously done repeatedly (dynamic) to obtain understanding of the meaning of maqashid sharia in Islam. This condition is indicated by increasing value, which means there is improvement in the learning process, so as to influence the level of maqasid sharia not only from the aspect of quantity, but also from the quality aspects of paying ZIS is notated with(MS(X)(.

( $M S(X)$ ( value will continue through the process of interaction, integration and evolution (IIE) to produce new theta . Related to this research is Muzaki who has chosen to pay his ZIS in Zakat Management Organization (OPZ) when having understanding of maqashid sharia that has been in induced knowledge, then he will be more confident to pay ZIS, thus increasing the ability to pay ZIS.

In Tawhidi Epistemology approach, the implementation of worship that has been studied by knowledge will produce new theta. This new thetawill be attached to the maqashid sharia that owned by muzaki(MS (. When muzaki can improve the quality and quantity of ZIS that has been paid, it will feel the impact of tranquility and comfort in life. These feelings will be shown in their behaviors and become motivated for other family members. This belief makes him becomea Muslim furthermore muslihasa person who has kindness both personally and socially. Or in other words, 'soleh' is the quality of kindness only for oneself, whereas 'muslih' the quality of kindness can penetrate and be the guidance of other people or society broadly in accordance with Islamic principles contained in maqashid sharia.

\section{CONCLUSION}

Muzaki's decision to pay ZIS in BAZNAS Jambi Province is influenced by maqashid sharia, positive and significant in perspective of Islamic Epistemology Approach. Muzaki who pays ZIS understand and believe the value contained in the maqashidsharia provides benefit for themself, family and society. So it could be motivatedmuzaki to increase the quality and quantity of charity in this case paying ZIS.

This research is only done on the national charity (BAZNAS) Agency of Jambi Province, the future of this research can be done on different organization of zakat (OPZ), namely the provincial BAZNAS, amil zakat institution (LAZ), and others. The involvement of many zakat management organizations (OPZ) aims to know the generalization of the behavior of muzaki in deciding to pay ZIS in the chosen zakat management organization (OPZ).

\section{REFERENCES}

Al-Qur'annul Karim

Ahmed, H. 2004. Zakah, Macroeconomic Policies, and Poverty Alleviation: Lessons from Simulations on Bangladesh. Journal of Islamic Economics, Banking and Finance, 81-105.

American Research Journal of Business and Management

Page 11 
The Effect of Maqashid Sharia on the Decision of Muzaki Paying Zakat in Organization of Zakat Management (OPZ)(Tawhidi Perspective Epistemology Approach)

Asy-Syatibi, al-Muwafaqat fi Ushul al-Syari ' ah , (Kairo: Musthafa Muhammad, t.th), Jilid 2, h. 374.

Chapra, M. U., 2013 Bank, I. D., Clark-Murphy, M., Gerrans, P., \& Speelman, C. (2009). Vision of Development in the Light of Maqāsid Al-Sharī 'ah. Journal of Family and Economic Issues, 30(1), 4-19. https://doi.org/10.1007/ s10834-008-9133-8

Chin. W .W (1998).The Partial Least Squares Approach for Strutual Equation Modeling. In G.A Marcoulides (Ed) Modern Methods for Bussinesresearch (pp. 295-336) . London : Lawrence Elbaum Associates.

Choudury M.A (1999). Comperative Economic Theory. Occidental and Islamic Perspective Boston-DordrechtLondon. Kluwer Academic Publisher.

Charles W. Lamb, Joseph F. Hair, Carl McDaniel. 2001. Pemasaran, Edisipertama. SalembaEmpat. Jakarta

Engel James F. Roger D. Blackwell and Paul W. Miniard, 1994 Consumer Behavior, (8 ed.) Forth Worth, TX: Dryden, 1995.

Farida, N., Azizi, H. 2008. Variabel-variabel yang MempengaruhiPembayaran Zakat Oleh Para Muzakki (StudiKasusPengelolaLembagaKeuanganSyariah di Kota Yogyakarta). Yogyakarta: Journal of Islamic Business and Economics, Vol. 2, No. 2.

Financial Times (2011). Islamic Finance: Financial Times Special Report, 15 December 2011. Available at: http:// im.ft-static.com/content/images/d1924118-2521-11e1-8bf9-00144feabdc0.pdf

Firmansyah.2013. Zakat SebagaiInstrumenPengentasanKemiskinan Dan KesenjanganPendapatan. JurnalEkonomidan Pembangunan Vol 21, No. 2, Desember 2013

Ghozali, I. (2015). Konsep, TeknikdanAplikasiMenggunakan Program SmartPLS 3.0, Edisi 2, Semarang: UniversitasDiponegoro Semarang.

Ghozali, Imam. 2014. Structural Equation Modeling, MetodeAlternatifdengan Partial Least Square (PLS). Edisi 4. Semarang :BadanPenerbitUniversitasDiponegoro.

Hafidhuddin, D. 2007. Zakat dalamPerekonomian Modern. GemaInsani Press, Jakarta, Indonesia.

Kahf, M. (1999). The Performance of the Institution of Zakah in Theory and Practice. International Conference on Islamic Economics towards the 21st Century. Kuala Lumpur: Malaysia.

Kasri, R. A. 2016. Maqasid al-Shariah and performance of zakah institutions.Kyoto Bulletin of Islamic Area Studies, 9(March), 19-41. Retrieved from http://www.asafas.kyoto-u.ac.jp/kias/pdf/kb9/03esf_03_kasri.pdf

LIPI (2009) PotensidanPeran Zakat DalamMengurangiKemiskinanStudikasusJawa Barat danJawaTimur

Mariyanti, Tatik. 2011. "Economic Social Factors Affecting Poverty Reduction in Indonesia in the Perspective of Islam." Doctoral Dissertation, University of Trisakti

Monzer, Kahf. 2000. Zakah Management in Some Muslim Societies. 2 ed. Jeddah: IRTI/IDB.

Mus'ab,A.2011.PengaruhReligiusitas, TingkatPenghasilan, danLayananTerhadapMinatMuzakkiUntukMembayar Zakat Maal di LAZIS NU. Yogyakarta: UIN SunanKalijaga.

PEBS-FEUI. 2011. Indonesia Shari'ah Economic Outlook (ISEO) 2011. Jakarta: LembagaPenerbit FEUI.

PIRAC. 2008. "MeningkatKesadarandanKapasitasMasyarakatdalamBerzakat". Diaksesdari

Praja. Juhaya S. EkonomiSyariah, (Bandung: CV PustakaSetia, 2012)

American Research Journal of Business and Management

Page 12 
The Effect of Maqashid Sharia on the Decision of Muzaki Paying Zakat in Organization of Zakat Management (OPZ)(Tawhidi Perspective Epistemology Approach)

Schiffman, L., \&Kanuk, L.L. (2007). Consumer Behavior. 9thEdition. New Jersey:Pearson Prentice Hall.

Syathibi, Abu Ishaq Ibrahim ibn Musa al-Gharnati al-, al-Muwafaqat fi Ushaul al-Ahkam, II, t.tp: Dar al-Fikr, t.th.

The Indonesian Institute. 2017. Center for public policy research. Update Indonesia. Volume XI, No. 2 - Februari 2017

Citation: Nurida Isnaeni, Yuswar Z. Basri, Tatik Mariyanti. "The Effect of Maqashid Sharia on the Decision of Muzaki Paying Zakat in Organization of Zakat Management (OPZ)(Tawhidi Perspective Epistemology Approach)" American Research Journal of Business and Management. 2018; 4(1): 1-13.

Copyright (C) 2018 Nurida Isnaeni, Yuswar Z. Basri, Tatik Mariyanti. This is an open access article distributed under the Creative Commons Attribution License, which permits unrestricted use, distribution, and reproduction in any medium, provided the original work is properly cited.

American Research Journal of Business and Management

Page 13 